\title{
Towards accurate exclusion of neonatal bacterial meningitis: a feasibility study of a novel 165 rDNA PCR assay
}

\author{
Arthur Abelian ${ }^{1 *}\left(\mathbb{D}\right.$, Thomas Mund ${ }^{2}$, Martin D. Curran ${ }^{3}$, Stuart A. Savill ${ }^{4}$, Nipa Mitra ${ }^{5}$, Carol Charan ${ }^{5}$, \\ Amanda L. Ogilvy-Stuart ${ }^{5}$, Hugh R. B. Pelham ${ }^{2}$ and Paul H. Dear ${ }^{6}$
}

\begin{abstract}
Background: PCRctic is an innovative assay based on 165 rDNA PCR technology that has been designed to detect a single intact bacterium in a specimen of cerebro-spinal fluid (CSF). The assay's potential for accurate, fast and inexpensive discrimination of bacteria-free CSF makes it an ideal adjunct for confident exclusion of bacterial meningitis in newborn babies where the negative predictive value of bacterial culture is poor. This study aimed to stress-test and optimize PCRctic in the "field conditions" to attain a clinically useful level of specificity.

Methods: The specificity of PCRctic was evaluated in CSF obtained from newborn babies investigated for meningitis on a tertiary neonatal unit. Following an interim analysis, the method of skin antisepsis was changed to increase bactericidal effect, and snap-top tubes (Eppendorf ${ }^{\mathrm{rm}}$ ) replaced standard universal containers for collection of CSF to reduce environmental contamination.

Results: The assay's specificity was $90.5 \%$ in CSF collected into the snap-top tubes - up from 60\% in CSF in the universal containers. The method of skin antisepsis had no effect on the specificity. All CSF cultures were negative and no clinical cases of neonatal bacterial meningitis occurred during the study.

Conclusions: A simple and inexpensive optimization of CSF collection resulted in a high specificity output. The low prevalence of neonatal bacterial meningitis means that a large multi-centre study will be required to validate the assay's sensitivity and its negative predictive value.
\end{abstract}

Keywords: Neonatal bacterial meningitis, Broad-range PCR, Ethidium monoazide

\section{Background}

The clinical signs of neonatal meningitis are very nonspecific [1] and the current UK practice is to test cerebrospinal fluid (CSF) for meningitis in all newborn babies with suspected sepsis and raised C-reactive protein [2]. With many babies exposed to antibiotics intrapartum [3] and with nearly all babies receiving antibiotics before the lumbar puncture [2], a negative result in CSF bacterial culture

\footnotetext{
* Correspondence: abelartur@doctors.org.uk

'Department of Paediatrics, Maelor Hospital, Betsi Cadwaladr University LHB, 12 Fleming Drive, Wrexham LL11 2BP, UK

Full list of author information is available at the end of the article
}

does not rule out bacterial meningitis [4-6]. CSF pleocytosis can be indicative of meningitis, but CSF microscopy can be difficult to interpret: (i) up to $50 \%$ of neonatal lumbar punctures result in blood-stained CSF $[7,8]$, (ii) there is uncertainty as to what constitutes a normal CSF white cell count in healthy babies $[9,10]$, and (iii) "normal" CSF microscopy does not exclude bacterial meningitis [11]. Even when blood cultures are positive, the bacteria in the blood do not necessarily match those in CSF [11].

Based on clinical and microbiological data [12-14], the rate of neonatal bacterial meningitis in the UK is low (0.2 to 0.3 per 1000 live births). This notwithstanding,

(c) The Author(s). 2020 Open Access This article is licensed under a Creative Commons Attribution 4.0 International License, which permits use, sharing, adaptation, distribution and reproduction in any medium or format, as long as you give appropriate credit to the original author(s) and the source, provide a link to the Creative Commons licence, and indicate if changes were made. The images or other third party material in this article are included in the article's Creative Commons licence, unless indicated otherwise in a credit line to the material. If material is not included in the article's Creative Commons licence and your intended use is not permitted by statutory regulation or exceeds the permitted use, you will need to obtain permission directly from the copyright holder. To view a copy of this licence, visit http://creativecommons.org/licenses/by/4.0/ The Creative Commons Public Domain Dedication waiver (http://creativecommons.org/publicdomain/zero/1.0/) applies to the data made available in this article, unless otherwise stated in a credit line to the data. 
20-40 newborn babies per 1000 live births are investigated for meningitis [15]. The overwhelming majority of these babies do not have bacterial meningitis $[6,15,16]$. However, poor sensitivity of CSF bacterial culture and uncertainties in the interpretation of CSF microcopy can result in unnecessary hospitalization and treatment, with associated costs and risks [17]. We therefore speculated that an assay sensitive enough to accurately discriminate bacteria-free CSF would facilitate accurate exclusion of bacterial meningitis, with early discontinuation of antibiotic treatment and discharge from hospital. To that end, we developed PCRctic - an assay based on the broad range $16 \mathrm{~S}$ rDNA PCR technology, enhanced to detect a single bacterium in a standard neonatal CSF specimen $(200 \mu \mathrm{l})$.

A recent Cochrane review highlighted limitations of the reported molecular assays for neonatal sepsis [18]. Multiplex PCR assays, which simultaneously test for a number of organisms, on the whole showed poor sensitivity and specificity for neonatal sepsis (76 and $81 \%$, respectively; based on six reports). The performance of multiplex PCR for neonatal meningitis remains to be addressed [19]. Standard broad-range $16 \mathrm{~S}$ rDNA PCR assays fared better but rely on high concentration of bacteria in the samples $\left(10^{2}-10^{3}\right.$ colony-forming units per milliliter [CFU/ml]) [20] and are therefore unlikely to have adequate sensitivity for accurate exclusion of meningitis.

The sensitivity of standard $16 \mathrm{~S}$ rDNA PCR is limited due to the universal detection of free bacterial DNA contaminating samples and reagents [21]. To address this limitation, PCRctic utilizes ethidium bromide monoazide - a photo-reactive DNA-binding agent [22] - to eliminate the unwanted free bacterial DNA. This then allows the sensitivity to be boosted by employing a nested PCR format to selectively detect any intact bacteria present in the specimen.

The broad range and high sensitivity of the assay promise an unprecedented scope for the evaluation of the bacterial carriage in clinical specimens but also make it vulnerable to false positive results due to the ubiquitous environmental bacteria. This feasibility study of PCRctic was conducted to establish the operating procedures that result in a clinically useful level of specificity.

\section{Methods}

\section{Study participants and oversight}

From October 2016 to September 2017 we recruited newborn babies of at least 34 weeks post-menstrual age undergoing lumbar puncture to exclude meningitis on either the postnatal wards or on the neonatal unit at the Rosie Hospital, Cambridge University Hospitals NHS Trust. Informed consent was obtained before CSF was analysed by PCRctic. UK National Research Ethics
Committee and UK Health Research Authority (HRA) approved the study.

\section{Study interventions}

All babies recruited into the study had their CSF tested by bacteriological culture and in PCRctic. The study had two phases. In the first, at least five drops of CSF were collected into each of three sterile universal containers (ISS Ltd., UK). CSF in two of these was tested using the standard laboratory assessment for meningitis, and, following parental consent, CSF in the third container was tested in PCRctic in the clinical microbiology laboratory, Addenbrookes Hospital, Cambridge University Hospitals NHS Trust. Whilst the $30 \mathrm{ml}$ sterile universal containers are routinely used across the UK for CSF collection, special care is needed to avoid contamination through the handling of the screw-on tops. In the second phase, CSF for PCRctic was collected into $1.5 \mathrm{ml}$ sterile individually sealed snap-top tubes (Eppendorf Biopur, Eppendorf AG, Germany). Lumbar puncture technique was as standard. Unisept (Molnlycke Healthcare Ltd., UK) solution of $0.05 \%$ chlorhexidine was used in the first phase of the study for skin antisepsis. This was changed to ChloraPrep (BD, UK), containing 2\% chlorhexidine and $70 \%$ alcohol for the second phase of the study.

\section{Interim analysis}

Results from the initial 39 samples suggested possible environmental contamination and the study protocol was amended to include individually sealed sterile snaptop tubes and ChloraPrep skin antisepsis (as above). The amendment was approved by HRA.

\section{Study outcome}

The primary outcome measure was the rate of false positive results. As this was a feasibility study, the results had no effect on patient care.

\section{Modified 16S rDNA PCR assay (PCRctic)}

PCRctic (Fig. 1) uses primers against the conserved regions of bacterial ribosomal DNA. Its sensitivity and specificity derive from a single-step, closed-tube nested PCR format employing external primers (25mers) with high $\operatorname{Tm}\left(\approx 75^{\circ} \mathrm{C}\right)$ at $50 \mathrm{nM}$ (30 cycles) [333F25 CCAGAC TCCTACGGGAGGCAGCAGT, 929R25 CCACATGCTC CACCGCTTGTGCGGG] and internal primers (19mers) with a low $\mathrm{Tm}\left(\approx 50{ }^{\circ} \mathrm{C}\right)$ at $0.25 \mu \mathrm{M}$ (40 cycles) [800F19 TAGTCCACGCCGTAAACGA, 907R19 CCGTCAATTC ATTTGAGTT]. Primers were designed against the conserved regions of the bacterial 16S rDNA gene. Briefly, 21, 397 rDNA gene sequences were downloaded and aligned, and a simple script was used to identify conserved portions. From these portions, primers were designed to have 

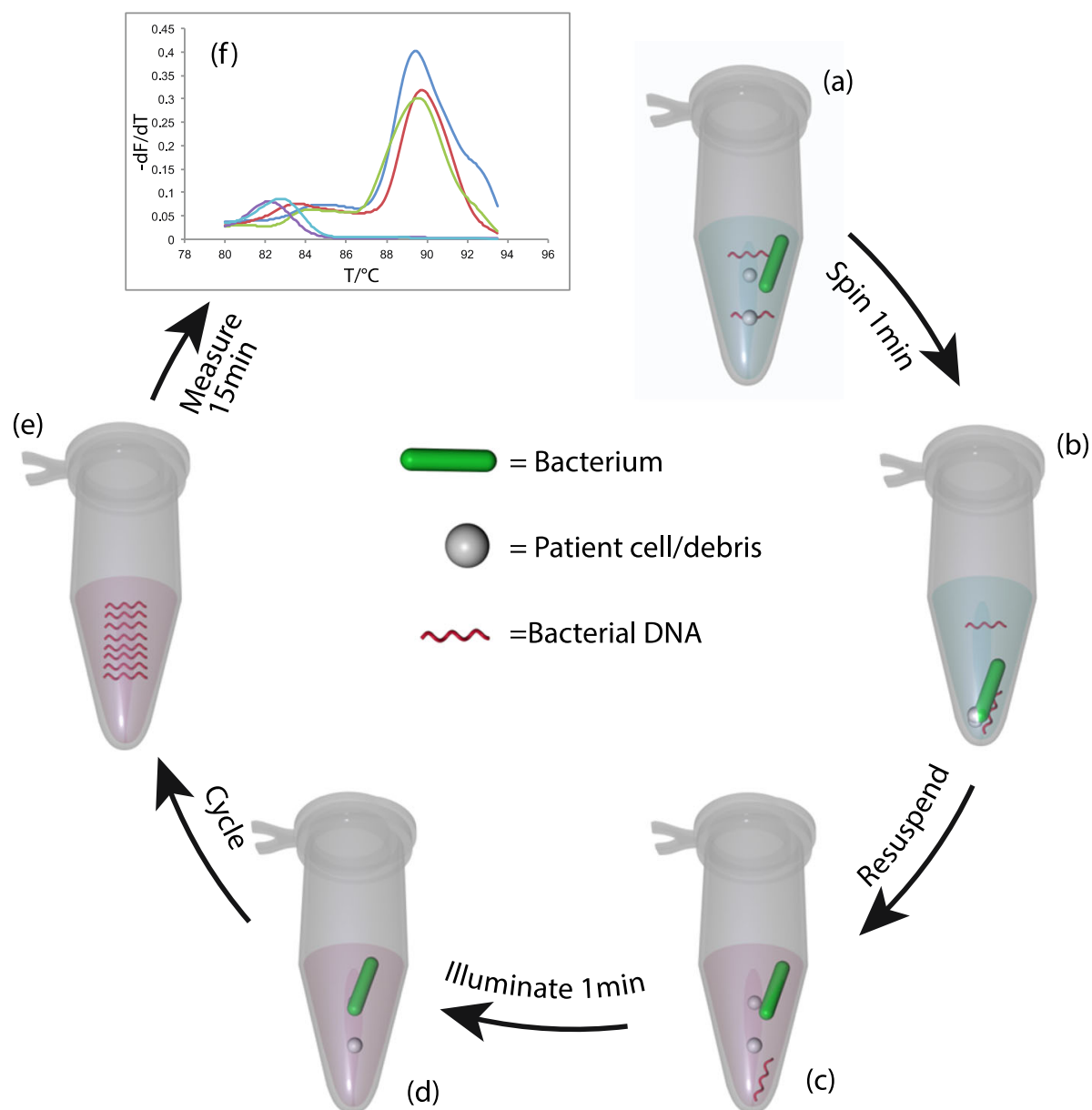

(b)

(d)
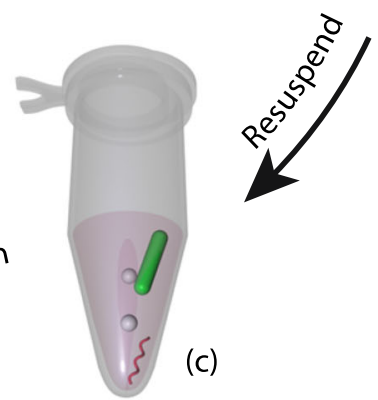

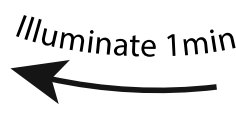

Fig. 1 PCRctic: a CSF samples; $\mathbf{b}$ Intact bacteria are pelleted along with patient cells and debris; c The pellet is resuspended in the assay mixture (PCR reagents, ethidium azide, buffer); $\mathbf{d}$ light activates the ethidium azide, destroying exposed DNA (from dead bacteria or from contaminants in the reagents) but leaving intact bacteria unaffected; during PCR $\mathbf{e}$, heat causes the bacteria to lyse, making their DNA available for amplification. $\mathbf{f}$ amplification products are then detected by a simple fluorometric assay (melting-curve analysis) using a widely-available real-time PCR machine. Total assay time is approximately $2 \mathrm{~h}$

a Tm (calculated as $2 x[\mathrm{~A}+\mathrm{T}]+4 \mathrm{x}[\mathrm{G}+\mathrm{C}]$ ) of $60-70{ }^{\circ} \mathrm{C}$ (outer primers) or $48-52^{\circ} \mathrm{C}$ (inner primers).

Contamination from free bacterial DNA was eliminated by the use of ethidium bromide monoazide (EtA) [22]. Exposure of the reaction tube to light $(530 \mathrm{~nm})$ for 1 min causes EtA to react covalently with DNA, rendering it non-amplifiable (Fig. 2). The same illumination also destroys any residual EtA. Importantly, EtA does not penetrate intact bacteria and can therefore be used in the presence of the target (intact) bacteria before these are lysed by heat in the first PCR cycle. Typically, $180 \mu \mathrm{l}$ of CSF were transferred into $0.2 \mathrm{ml}$ PCR tubes and pelleted in a microfuge (Eppendorf: 5424, Rotor: FA-45-24-11) for $2 \mathrm{~min}$ at $20.000 \mathrm{~g}$. After carefully

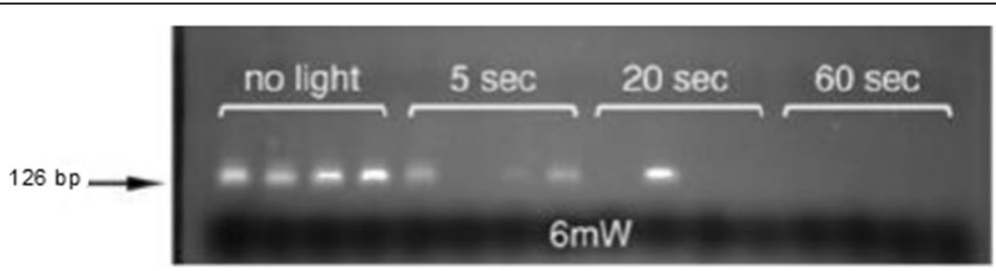

Fig. 2 Elimination of false positives due to contaminating bacterial DNA, by photoactivation of EtA. A band at 126 bp indicates a positive result. Without photoactivation ("no light") all specimens are positive. Exposure to light for $60 \mathrm{~s}$ completely eliminated false positive signal. Electrophoresis of PCRctic products in 3\% agarose gel 
removing the supernatant with a sterilized gel-loading tip, $10 \mu \mathrm{l}$ of a previously-frozen PCR mastermix $(80 \mu \mathrm{l}$ KOD 10x buffer, $80 \mu \mathrm{l}$ 10x dNTPs, $64 \mu \mathrm{l} 25 \mathrm{mM} \mathrm{MgSO}_{4}$, $8 \mu \mathrm{l} \mathrm{KOD} \mathrm{HotStart} \mathrm{enzyme,} 40 \mu \mathrm{l} 20 \mathrm{x}$ primer mix, $510 \mu \mathrm{l}$ HPLC-grade water, $16 \mu \mathrm{l} \mathrm{10x} \mathrm{SYBR} \mathrm{Green,} 1.6 \mu \mathrm{l} 25 \mu \mathrm{M}$ ROX, $1.25 \mu \mathrm{l} 2.4 \mathrm{mM}$ EtA) were added. The closed PCR tubes were then illuminated as above to photoactivate EtA. The samples were then amplified on a quantitative PCR (qPCR) system (Applied Biosytems ViiA 7; $95^{\circ} \mathrm{C} \times$ 3 min, then 30 cycles of: $94{ }^{\circ} \mathrm{C} \mathrm{x} 10 \mathrm{~s}, 70^{\circ} \mathrm{C}$ x 20 s, $72^{\circ} \mathrm{C} \mathrm{x}$ 30 s; then 40 cycles of $94^{\circ} \mathrm{C} \times 10 \mathrm{~s}, 50^{\circ} \mathrm{C} \times 20 s, 72^{\circ} \mathrm{C} \mathrm{x}$ 30 ) followed by a melting curve analysis.

Negative controls tested the mastermix in empty tubes, positive controls used spiked mastermix under the same experimental conditions (all done using the same hood, equipment and environment). Bacterial strains used were E. coli (DH5-alpha and ATCC 25922), S. aureus (ATCC 29213), S. agalactiae (NCTC 8181) or L. monocytogenes (NCTC 7973). In CSF samples spiked with bacteria, PCRctic reliably detected as few as 1.5 CFUs (Fig. 3a\&b and Fig. 4). Positives gave a single melt at $86-90^{\circ} \mathrm{C}$, in negatives primer dimers gave a single $\left(72-75^{\circ} \mathrm{C}\right.$ ) or double peak between 72 and $82^{\circ} \mathrm{C}$ (not shown), which served as an internal control. For confirmation, the samples were run on $3 \%$ agarose minigels detecting the expected band of about $126 \mathrm{bp}$ (size varied slightly depending on bacterial species). Positives were purified from gels and sequenced. Where possible, mixed samples were re-cloned into pBluescript vector (Agilent Technologies, USA) and individually sequenced.

\section{Statistical analysis}

A nonparametric Mann-Whitney $U$ test was used for the significance of the difference between the studied groups. Bayesian statistics were used to estimate the significance of the positive results under different prevalence, specificity, and sensitivity conditions.

\section{Results}

In total, CSF from 73 babies was tested in PCRctic in parallel with standard microbiological testing. All babies received antibiotics before lumbar puncture. All bacterial cultures (blood and CSF) were negative, and all babies, including those with CSF white cell count of $\geq 20$ per microliter (Table 1), had no neurological signs suggestive of meningitis and no baby was treated for bacterial meningitis.

The first 39 samples were collected into universal containers and were from babies where Unisept was used for skin antisepsis. Sixteen of these were positive in PCRctic (41\%). Sequencing revealed a diverse group of

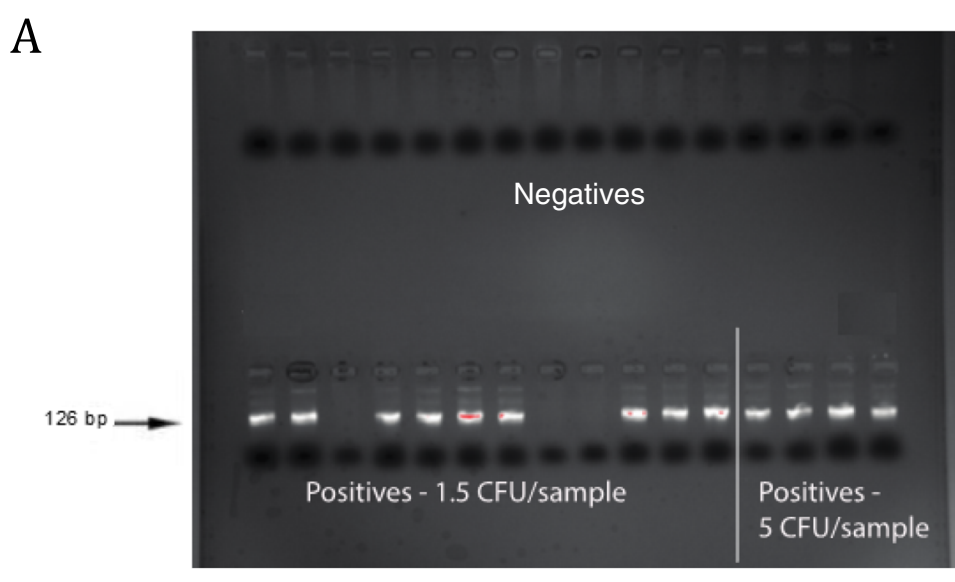

B

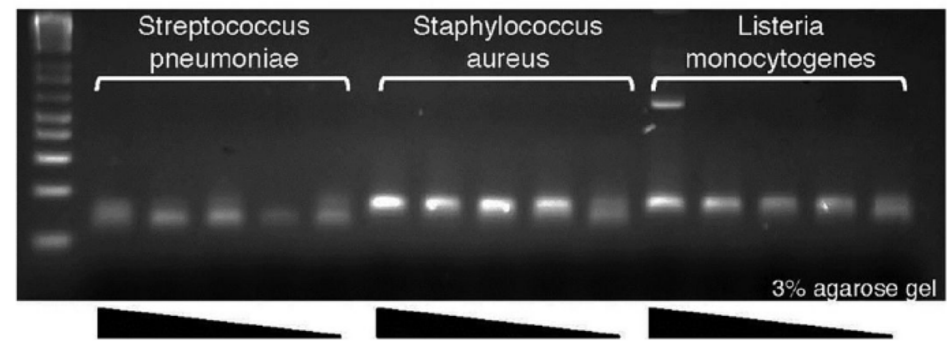

Fig. 3 Sensitivity of PCRctic with 200- $\mu$ C CSF samples "spiked" with bacteria. Electrophoresis of PCRctic products in 3\% agarose gel. a E. coli (DH5alpha strain) were titrated to an average of 1.5 or 5 CFU/sample. Occasional negative results at $1.5 \mathrm{CFU} / \mathrm{sample}$ can be accounted for by the random nature of titration at this level: with an average of $1.5 \mathrm{CFU} / \mathrm{sample}$, approximately $22 \%$ of samples should be negative. $\mathbf{b}$ Streptococcus pneumoniae, Staphylococcus aureus and Listeria monocytogenes (patient-derived isolates) were titrated by 10-fold dilutions to $\leq 5$ CFU/sample 


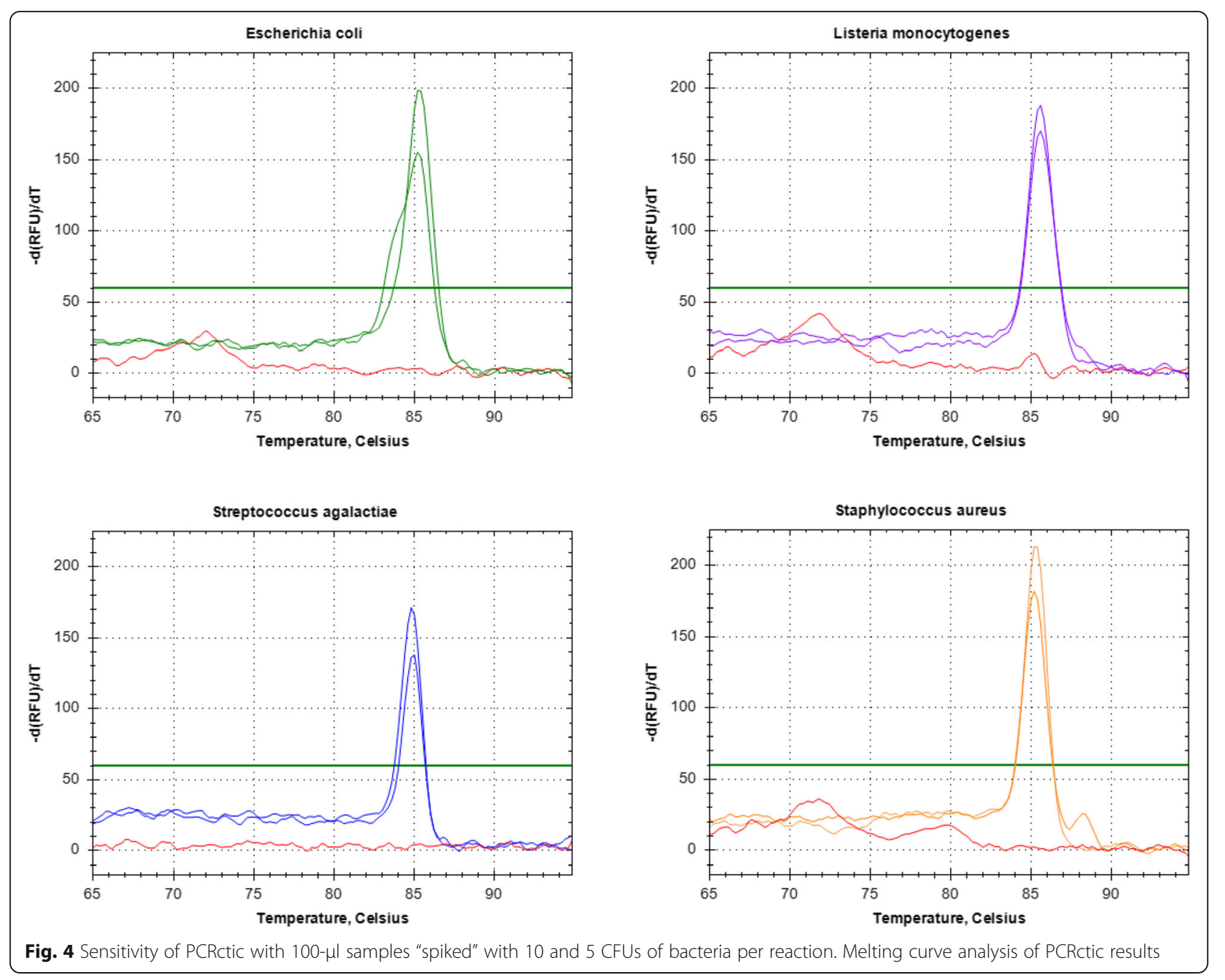

Gram-positive and Gram-negative microorganisms, some of which belonged to bacterial families associated with neonatal meningitis (Table 1, samples 1-39; Fig. 5).

At this point, considering the diversity of the bacteria detected by PCRctic, we questioned whether these originated from the CSF or were environmental contaminants acquired during lumbar puncture. We identified two possible "weak points" which might lead to environmental contamination. One was the manner of CSF collection. The universal containers may become contaminated when their screw-on tops are left on non-sterile surface at cot side during CSF collection. These were therefore replaced with individually sealed sterile snap-top Eppendorf tubes. The second "weak point" was skin antisepsis. Containing only $0.05 \%$ chlorhexidine, Unisept may have been bacteriostatic rather than bactericidal and was replaced with ChloraPrep (2\% chlorhexidine and 70\% alcohol) - this change was serendipitous as it reflected the comprehensive change of the unit's practice for all procedures requiring aseptic technique.
Skin antisepsis with ChloraPrep but using universal containers (samples 40-52, Table 1) resulted in five PCRctic positive samples $(5 / 13$; 38\%). Skin antisepsis with ChloraPrep and collection of CSF into snap-top Eppendorf tubes (samples 53-73, Table 1) resulted in two PCRctic positive samples $(2 / 21$; 9.5\%): a Geobacter (an environmental bacterium) and a mixed species (Fig. 5). The difference between the rates of positive results in the specimens collected into the universal containers (samples 1-52) and those in the snap-top tubes (samples 53-73) was statistically significant in the Mann-Whitney $U$ test $(U=377.5, P=0.04$ twotailed). Of the 23 negative controls only one was positive in PCRctic (4\%; sequencing revealed Bacillus). There was no statistically significant relationship between PCRctic result and the number of CSF white cells $(\mathrm{U}=384.5, P=0.15$ twotailed) or red cells $(\mathrm{U}=361.5, P=0.32$ two-tailed).

\section{Discussion}

Neonatal bacterial meningitis is a devastating illness with high mortality and residual neurodisability in the survivors 
Table 1 CSF microscopy, culture and PCRctic results in universal containers (samples 1-52) and snap-top tubes (samples 53-73)

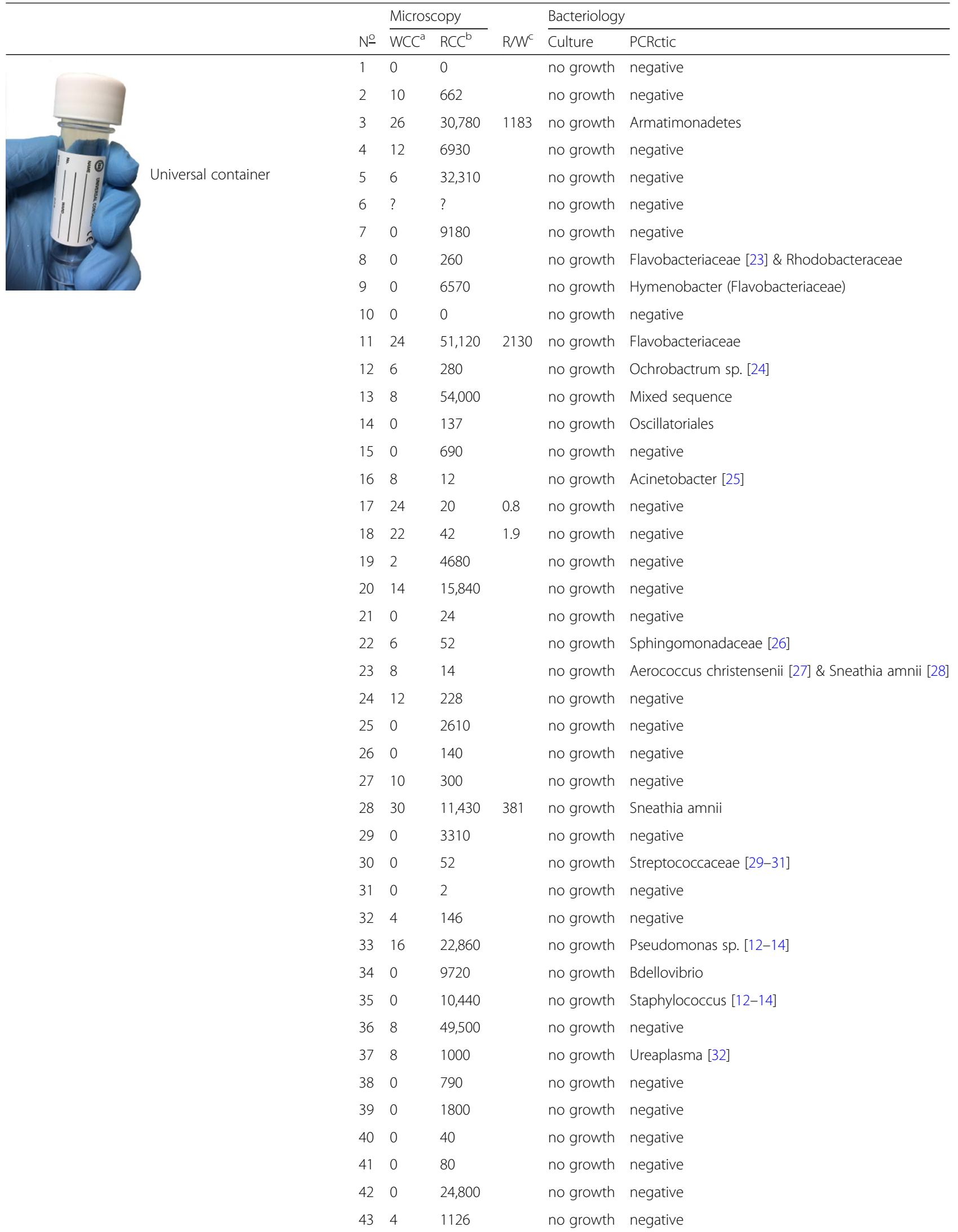


Table 1 CSF microscopy, culture and PCRctic results in universal containers (samples 1-52) and snap-top tubes (samples 53-73) (Continued)

\begin{tabular}{|c|c|c|c|c|c|c|}
\hline & \multirow[b]{2}{*}{ № } & \multicolumn{2}{|c|}{ Microscopy } & \multirow[b]{2}{*}{$\mathrm{R} / \mathrm{W}^{\mathrm{C}}$} & \multicolumn{2}{|l|}{ Bacteriology } \\
\hline & & $\overline{\text { WCC }^{a}}$ & $\mathrm{RCC}^{\mathrm{b}}$ & & Culture & PCRctic \\
\hline & 44 & 0 & 38 & & no growth & negative \\
\hline & 45 & 10 & 7560 & & no growth & Cloacibacterium rupense \\
\hline & 46 & 8 & 9360 & & no growth & negative \\
\hline & 47 & 4 & 284 & & no growth & Mixed sequence \\
\hline & 48 & 0 & 18,900 & & no growth & negative \\
\hline & 49 & 0 & 0 & & no growth & negative \\
\hline & 50 & 0 & 6 & & no growth & Methylobacterium sp. \\
\hline & 51 & 4 & 10,170 & & no growth & Pedobacter suwonensis \\
\hline & 52 & 0 & 0 & & no growth & Staphylococcus aureus \\
\hline & 53 & 16 & 22,860 & & no growth & negative \\
\hline & 54 & 0 & 40 & & no growth & negative \\
\hline & 55 & 2 & 70 & & no growth & negative \\
\hline Snap-top tube ("Eppendorf") & 56 & 0 & 3420 & & no growth & negative \\
\hline & 57 & 0 & 0 & & no growth & negative \\
\hline & 58 & 2 & 2088 & & no growth & negative \\
\hline & 59 & 42 & 21,690 & 516 & no growth & negative \\
\hline & 60 & 0 & 1080 & & no growth & negative \\
\hline & 61 & 0 & 40 & & no growth & negative \\
\hline & 62 & 0 & 132 & & no growth & negative \\
\hline & 63 & 12 & 22 & & no growth & Geobacter \\
\hline & 64 & 4 & 16 & & no growth & negative \\
\hline & 65 & 10 & 1940 & & no growth & negative \\
\hline & 66 & 8 & 4 & & no growth & negative \\
\hline & 67 & 4 & 36 & & no growth & Mixed sequence \\
\hline & 68 & 0 & 2 & & no growth & negative \\
\hline & 69 & 0 & 8820 & & no growth & negative \\
\hline & 70 & 0 & 8010 & & no growth & negative \\
\hline & 71 & 6 & 4 & & no growth & negative \\
\hline & 72 & 51 & 406,800 & 7976 & no growth & negative \\
\hline & 73 & 6 & 12 & & no growth & negative \\
\hline
\end{tabular}

${ }^{a}$ WCC - CSF White blood cell count, per microlitre

${ }^{\mathrm{b}} \mathrm{RCC}-\mathrm{CSF}$ red blood cell count, per microlitre

${ }^{c} \mathrm{R} / \mathrm{W}$ - the ratio of CSF red to white cells (calculated only for samples with $\geq 20$ white cells in microliter [10]. The ratio that allows accurate exclusion of neonatal bacterial meningitis remains uncertain [8]

[33-35]. Early diagnosis improves the outcomes [36]. In older children, accurate diagnosis of bacterial meningitis rests on the detection of bacteria in the CSF of a patient with clinically suspected meningitis (high temperature, headache, neck stiffness, photophobia, seizures). Accurate diagnosis of neonatal bacterial meningitis or lack thereof is more difficult for two reasons: (i) newborn babies do not develop stiff neck, photophobia or other clinical signs indicative of meningitis in older age groups [35], (ii) the sensitivity of the detection method (bacterial culture) is poor. For example, the NeonIn network reported only 41 positive CSF cultures in the period from 2005 to 2014 [37]: a rate of around 0.1 per 1000 live births, which possibly underestimates the incidence by as much as $50 \%$ [12-14]. Similarly, in a recent large multicenter study in Ireland, bacterial CSF culture missed seven cases of definite Group B Streptococcal meningitis out of 12 [6]. For these reasons, in many babies bacterial meningitis cannot be promptly confirmed or ruled out with confidence. Consequently, there is a risk of over-treatment with 

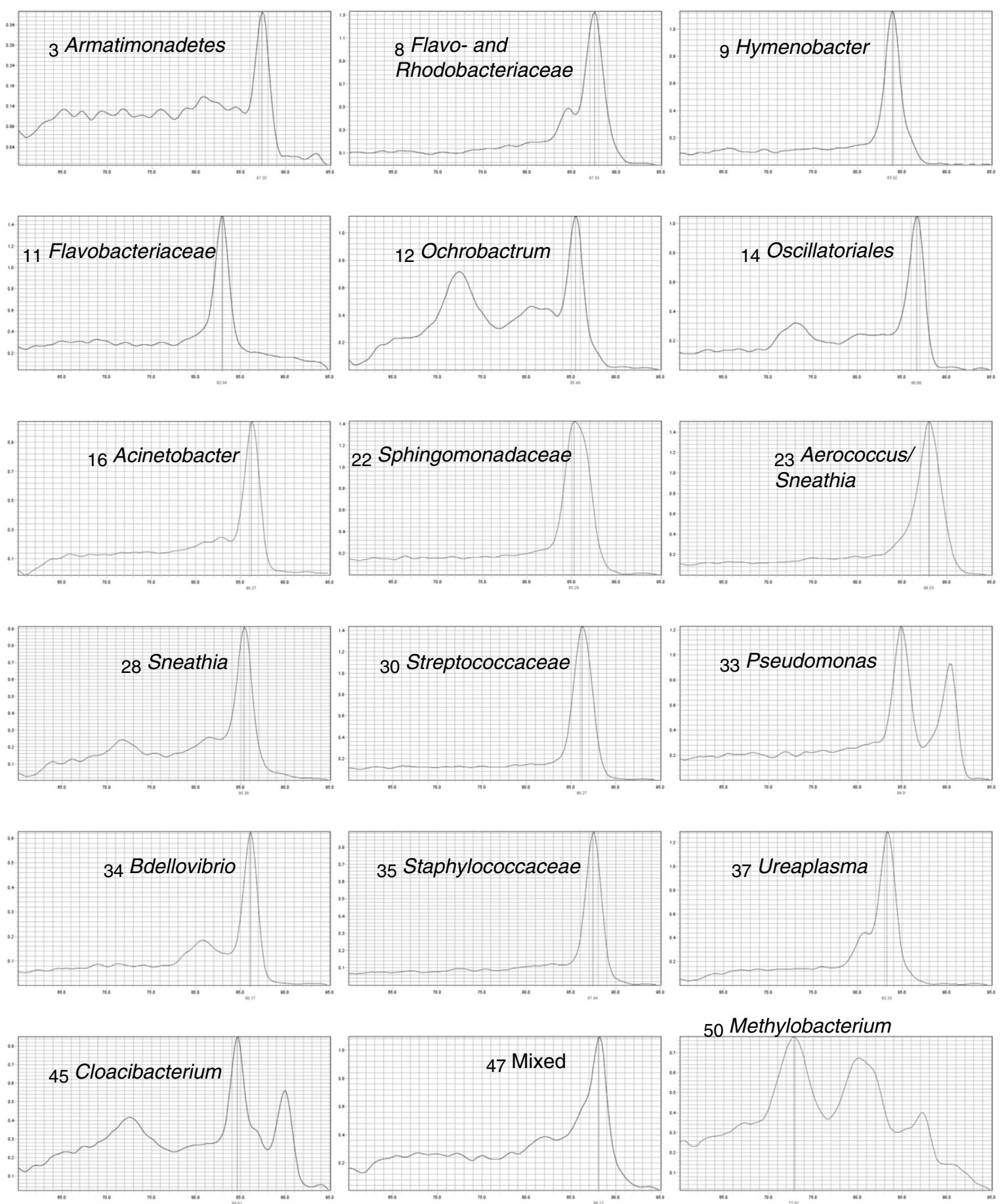

50 Methylobacterium
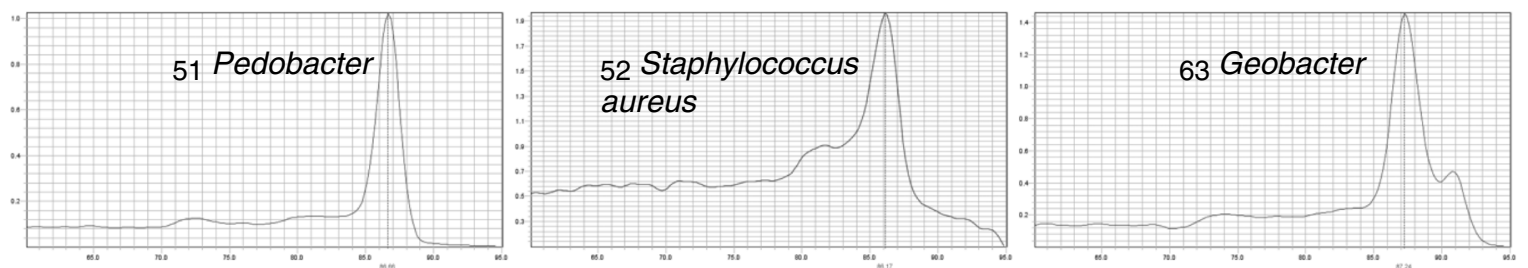

Fig. 5 Melting curve analysis of PCRctic results obtained from clinical specimens 
unnecessary hospitalisation and antibiotic exposure - a frequent problem encountered in the management of paediatric meningitis [17].

The sensitivity of the detection can be increased many-fold by PCR, which has already been widely used for diagnosis of infections (including meningitis) [38]. PCR assays can be either bacterium-specific or broadrange. Bacterium-specific PCR has not been widely used in the diagnosis of meningitis in newborn babies since it can be caused by many types of bacteria: some more common (e.g. Group B Streptococcus, Escherichia coli) $[12-14,35]$, some less so [23-32, 39-48].

In contrast, a broad-range PCR that targets the DNA region highly conserved between different types of bacteria (16S rDNA PCR), can, with few exceptions, detect bacteria of any type [21]. Until recently, the sensitivity of such broad-range PCR could not be fully harnessed due to the contamination with free bacterial DNA in the sample or in the reagents, making it inferior to bacterium-specific PCR to the order of one to two logs [21, 49].

Based on 16S rDNA PCR technology, PCRctic can detect virtually any type of bacterium. Through elimination of free bacterial DNA it can fully realize its sensitivity and detect single numbers of intact bacteria in the specimen just as a well-designed bacterium-specific PCR can $[6,50]$. These two features produce an ideal format for accurate identification of bacteria-free specimens. We hypothesized that it will have a small but clinically acceptable rate of false positive results, and a very high negative predictive value. These features can be especially useful in neonatal infection where the vast majority of tested babies do not have infection and early accurate discrimination of negative samples may assist in discontinuing or even withholding antibiotics [51, 52]. In babies with meningitis, the positive signal in PCRctic signifies the presence of bacteria with intact cellular wall. Such bacteria potentially remain viable for up to 21 days, which dictates the length of antibiotic treatment $[53,54]$.

Whereas skin antisepsis with either Unisept or ChloraPrep resulted in the same rate of positive results in universal containers (about 40\%), the collection into snaptop tubes significantly reduced the level to $9.5 \%$. Thus a simple and low-cost optimization of CSF handling increased the specificity of the assay from $\approx 60 \%$ ( 21 false positives out of 52 negative specimens) to $90.5 \%$ (two false positives out of 21 negative specimens). The format therefore addresses both types of environmental contamination: eliminates contaminating free bacterial DNA (ethidium azide) and reduces the risk of contamination with environmental bacteria (snap-top tubes). The performance of the negative controls (one positive out of 23) indicates that the limit of the assay's specificity is around $96 \%$. The assay is inexpensive: the cost of reagents is significantly less than $\$ 1$, the cost of a sterile
Table 2 Bayesian analysis of the positive and negative results

\begin{tabular}{llll}
\hline & \multicolumn{3}{l}{ Specificity (\%) } \\
\cline { 2 - 4 } & 90 & 96 & 99 \\
\hline Sensitivity (\%) $^{\mathrm{a}}$ & 99 & 99 & 99 \\
Prevalence $^{\mathrm{b}}$ & $1 / 150$ & $1 / 150$ & $1 / 150$ \\
Negative predictive value $_{\text {Positive predictive value }}$ & 0.999 & 0.999 & 0.999 \\
\hline
\end{tabular}

${ }^{a}$ assumed for the purposes of this analysis and is based on the reported

sensitivity of a rigorously-designed bacterium-specific qPCR assay [6]

${ }^{\mathrm{b}}$ prevalence amongst babies tested for meningitis as based on our

practice [15]

snap-top tube is $\$ 0.23$. The feedback from the clinical staff was that the snap-top tubes were easy to use and no handling-related issues were reported.

Application of Bayesian analysis shows that with these false-positive rates (and assuming the assay's sensitivity of $99 \%$ and the prevalence of bacterial meningitis of one in 150 tested babies), the chance that a positive result is truly positive (the positive predictive value) will always be less than $50 \%$ (Table 2). Thus, one important consequence of the low prevalence of neonatal meningitis is that the clinician will always have to interpret positive results cautiously, within the context of baby's condition and other laboratory data. Another consequence is that the negative predictive value of an accurate negative result is extremely high, underscoring the advantage of such an approach for accurate exclusion of bacterial meningitis.

\section{Conclusion}

In this feasibility study, an optimization of neonatal CSF collection resulted in a high specificity $16 \mathrm{~S}$ rDNA PCR output. This study was underpowered to test the assay's sensitivity. In fact, based on the significance level of $\leq 5$ and $80 \%$ power, 12 cases of meningitis will be required to demonstrate a $40 \%$ improvement in sensitivity against bacterial CSF culture, and 49 cases to demonstrate a $20 \%$ improvement [55]. With the prevalence of around 0.3 per 1000 live births, the population that will need to be involved in such a cross-sectional study is between 40,000 to 160,000 live born babies. Clearly, a large multicenter study will be required. The feasibility study reported here was an important step in that direction.

\section{Abbreviations}

PCR: Polymerase chain reaction; CFU: Colony-forming unit; EtA: Ethidium monoazide bromide; KOD: Thermococcus kodakaraensis; ROX: Rhodamine X

\section{Acknowledgements}

The authors are grateful to the parents and staff on NICU and Lady Mary Ward at Rosie Hospital for their part in this study, to Dr. Jim Turner for advice on statistical analysis, and to David Williams for the supply of bacteria of defined CFU per millilitre. 


\section{Dedication}

Shortly after the submission of the revised manuscript, Dr. Paul Dear was unexpectedly taken ill and tragically passed away. He was a friend and a hugely respected colleague, whose pioneering work on highly precise genome editing came to a premature end. We salute his life, in which science was raison d'être.

\section{Authors' contributions}

AA wrote the initial and subsequent drafts and was the chief investigator, TM, SS, MDC and HRBP conducted and analysed CSF testing in PCRctic, NM CC, ALO-S - conducted the study in Rosie Hospital, PHD designed and optimised the assay for CSF, all authors contributed to the manuscript, tables and figures, and have read and approved the final draft.

\section{Funding}

The study was funded by the UK Medical Research Council via LMB block grant (grant recipient HRBP).

\section{Availability of data and materials}

The datasets used and/or analysed during the current study are available from the corresponding author on reasonable request.

\section{Ethics approval and consent to participate}

The study was approved by Wales Research Ethics Committee 5 (Bangor), Health and Care Research Wales. Reference number 16/WA/0187. Parents of all participants provided written consent for the study.

\section{Consent for publication}

Not applicable.

\section{Competing interests}

The authors declare that they have no competing interests.

\section{Author details}

'Department of Paediatrics, Maelor Hospital, Betsi Cadwaladr University LHB, 12 Fleming Drive, Wrexham LL11 2BP, UK. ${ }^{2}$ MRC Laboratory of Molecular Biology, Cambridge, UK. ${ }^{3}$ Clinical Microbiology, Public Health England, Addenbrookes Hospital, Cambridge, UK. ${ }^{4}$ North Wales Clinical Research Centre, Betsi Cadwaladr University LHB, Wrexham, UK. ${ }^{5}$ Rosie Hospital Cambridge, UK. ${ }^{6}$ Mote Research Ltd., Babraham, Cambridge, UK.

Received: 13 November 2019 Accepted: 15 June 2020

Published online: 22 June 2020

\section{References}

1. Okike IO, Ladhani SN, Anthony M, et al. Assessment of healthcare delivery in the early management of bacterial meningitis in UK young infants: an observational study. BMJ Open. 2017;7(8):e015700.

2. Neonatal infection (early onset): antibiotics for prevention and treatment. National Institute for Health and Care Excellence Clinical Guideline 149 (2012). Available at https://www.nice.org.uk/guidance/cg149 (last accessed June 2020).

3. Bianco A, Larosa E, Pileggi C, Pavia M. Appropriateness of intrapartum antibiotic prophylaxis to prevent neonatal group B streptococcal disease. PLoS One. 2016;11(11):e0166179.

4. Riordan FAl, Cant AJ. When to do a lumbar puncture. Arch Dis Child. 2002 87:235-7.

5. Kanegaye JT, Soliemanzadeh P. Bradley JS. Lumbar puncture in pediatric bacterial meningitis: determining the time interval for recovery of cerebrospinal fluid pathogens after parenteral antibiotic pretreatment. Pediatrics. 2001;108:1169-74.

6. Morrissey SM, Nielsen M, Ryan L, et al. Group B streptococcal PCR testing in comparison to culture for diagnosis of late onset bacteraemia and meningitis in infants aged 7-90 days: a multi-Centre diagnostic accuracy study. Eur J Clin Microbiol Infect Dis. 2017;36:1317-24.

7. Yogev R. Meningitis. In: Jenson HB, Baltimore RS, editors. Pediatric infectious diseases. Philadelphia: WB Saunders; 2002. p. 630-50.

8. Srinivasan L, Harris MC, Shah SS. Lumbar puncture in the neonate: challenges in decision making and interpretation. Semin Perinatol. 2012;36: 445-53.
9. Martin-Ancel A, Garcia-Alix A, Salas S, et al. Cerebrospinal fluid leucocyte counts in healthy neonates. Arch Dis Child Fetal Neonatal Ed. 2006;91:F3578.

10. Kestenbaum LA, Ebberson J, Zorc JJ, et al. Defining cerebrospinal fluid white blood cell count reference values in neonates and young infants. Pediatrics. 2010;125:257-64.

11. Garges HP, Moody MA, Cotton CM, et al. Neonatal meningitis: what is the correlation among the cerebrospinal fluid cultures, blood cultures and cerebrospinal fluid parameters? Pediatrics. 2006;117:1094-100.

12. De Louvois J, Blackbourn J, Hurley R, Harvey D. Infantile meningitis in England and Wales: a two year study. Arch Dis Child. 1991;66:603-7.

13. Holt DE, Halket S, de Louvois J, Harvey D. Neonatal meningits in England and Wales: 10 years on. Arch Dis Child Fetal Neonatal Ed. 2001;84:F85-9.

14. Okike IO, Johnson AP, Henderson KL, et al. Incidence, etiology, and outcome of bacterial meningitis in infants aged $<90$ days in the United Kingdom and Republic of Ireland: prospective, enhanced, national population-based surveillance. Clin Infect Dis. 2014;59:e150-7.

15. Abelian A, Pritchard I. Neonatal bacterial meningitis: has time come for polymerase chain reaction? J Pediatr Infect Dis. 2011;6:227-9.

16. Eldadah M, Frenkel LD, Hiatt IM, et al. Evaluation of routine lumbar punctures in newborn infants with respiratory distress syndrome. Pediatr Infect Dis J. 1987;6:243-6.

17. Ramasamy R, Willis L, Kadambari S, et al. Management of suspected paediatric meningitis: a multicentre prospective cohort study. Arch Dis Child. 2018;103:1114-8.

18. Pammi M, Flores A, Versalovic J, Leeflang MM. Molecular assays for the diagnosis of sepsis in neonates. Cochrane Database Syst Rev. 2017: 2CD011926. https://doi.org/10.1002/14651858.CD011926.pub2.

19. Graf EH, Farquharson MV, Cardenas AM. Comparative evaluation of the FilmArray meningitis/encephalitis molecular panel in a pediatric population. Diagn Microbiol Infect Dis. 2017;87:92-4.

20. Liu CL, Ai HW, Wang WP, et al. Comparison of 165 rRNA gene PCR and blood culture for diagnosis of neonatal sepsis. Arch Pediatr. 2014;21:162-9.

21. Patel A, Harris KA, Fitzgerald F. What is broad range $165 \mathrm{rDNA}$ PCR? Arch Dis Child E P. 2017;102:261-4.

22. Nocker A, Camper AK. Selective removal of DNA from dead cells of mixed bacterial communities by use of ethidium monoazide. Appl Environ Microbiol. 2006;72:1997-2004.

23. Boo NY, Lim VK, Yakin FM, Sakijan AS. Management of Flavobacterium meningitis in the neonates: experience with 18 consecutive cases. Singap Med J. 1989;30:177-83.

24. Chang HJ, Christenson JC, Pavia AT, et al. Ochrobactrum anthropi meningitis in pediatric pericardial allograft transplant recipients. J Infect Dis. 1996;173:656-60.

25. Hu J, Robinson JL. Systematic review of invasive Acinetobacter infections in children. Can J Infect Dis Med Microbiol. 2010;21:83-8.

26. Marbjerg LH, Gaini S, Justesen US. First report of Sphingomonas koreensis as a human pathogen in a patient with meningitis. J Clin Microbiol. 2015;53: 1028-30.

27. Nathavitharana KA, Arseculeratne SN, Aponso HA, et al. Acute meningitis in early childhood caused by Aerococcus viridans. BMJ (Clin Res Ed). 1983;286: 1248

28. Devi U, Bora A, Das JK, et al. Sneathia species in a case of neonatal meningitis from Northeast India. Oxf Med Case Reports. 2014;2014:112-4.

29. Atala A, Correa CN, Correa WN, et al. Meningitis caused by Streptobacillus moniliformis. Rev Paul Med. 1973;82:175-8.

30. Hmamai F, Oulmaati A, Mahmoud M, et al. Neonatal group a streptococcal meningitis and portal vein thrombosis: a casual association? Arch Pediatr. 2014:21:1020-3.

31. Beneteau A, Levy C, Foucaud P, et al. Childhood meningitis caused by Streptococcus bovis group: clinical and biologic data during a 12-year period in France. Pediatr Infect Dis J. 2015;34:136-9.

32. Glaser $\mathrm{K}$, Wohlleben M, Speer CP. An 8-month history of meningitis in an extremely low birth weight infant? - long-lasting infection with Ureaplasma parvum. Z Geburtshilfe Neonatol. 2015;219:52-6.

33. Hristeva L, Booy R, Bowler I, Wilkinson AR. Prospective surveillance of neonatal meningitis. Arch Dis Child. 1993;69:14-8.

34. Bedford $\mathrm{H}$, de Louvois J, Halket $\mathrm{S}$, et al. Meningitis in infancy in England and Wales: follow up at age 5 years. BMJ. 2001;323:533-6.

35. Ku LC, Boggess KA, Cohen-Wolkowiez M. Bacterial meningitis in the infant. Clin Perinatol. 2015;42:29-45. 
36. Heath PT, Okike IO, Oeser C. Neonatal meningitis: can we do better? Adv Exp Med Biol. 2011;719:11-24.

37. Cailes B, Kortsalioudaki C, Buttery J, et al. Epidemiology of UK neonatal infections: the neonIN infection surveillance network. Arch Dis Child Fetal Neonatal Ed. 2018;103:F547-53.

38. Ginn AN, Halliday CL, Douglas AP, Chen SC-A. PCR-based tests for the early diagnosis of sepsis. Where do we stand? Curr Opin Infect Dis. 2017;30:56572.

39. Siwakoti S, Bajracharya S, Adkiharee N, et al. Early-onset neonatal meningitis caused by an unusual pathogen - Moraxella catarrhalis. Case Rep Pediatr. 2019. Published online Jan 9. https://doi.org/10.1155/2019/4740504.

40. Decroix V, Goudjil S, Kongolo G, Mammeri H. 'Leptotrichia amnionii', a newly reported cause of early onset neonatal meningitis. J Med Microbiol. 2013;62:785-8.

41. Tokieda K, Morikawa Y, Maeyama K. Clinical manifestations of Bacillus cereus meningitis in newborn infants. J Paediatr Child Health. 1999;35:582-4.

42. Tall BD, Chen Y, Yan Q, et al. Cronobacter: an emergent pathogen causing meningitis to neonates through their feeds. Sci Prog. 2014;97:154-72.

43. Devi U, Mahata J. Neonatal meningitis due to Neisseria meningitides serogroup Y. Indian Pediatr. 2014;51:757.

44. Yamaguchi $\mathrm{H}$, Tamura T, Abe M, et al. Prolonged incubation period in neonatal Pasteurella multocida meningitis and bacteremia. Pediatr Int. 2014; 56:e79-81.

45. Ivády B, Szabó D, Damjanova I, et al. Recurrent outbreaks of Serratia marcescens among neonates and infants at a pediatric department: an outbreak analysis. Infection. 2014;42:891-8.

46. Takahasi Y, Ishiwada N, Tanaka J, et al. Streptococcus gallolyticus subsp. pasteurianus meningitis in an infant. Pediatr Int. 2014;56:282-5.

47. Ikeda N, Suganuma H, Ohkawa N, et al. Measurement of cytokine levels in cerebrospinal fluid over time in neonatal Enterococcal meningitis. Pediatr Int. 2014;56:e45-7.

48. Bowe AC, Gischer M, Waggoner-Fountain LA, et al. Salmonella berta meningitis in a term neonate. J Perinatol. 2014;34:798-9.

49. Esparcia O, Mentemayor M, Gonovart G, et al. Diagnostic accuracy of a $16 \mathrm{~S}$ ribosomal DNA gene-based molecular technique (RT-PCR, microarray, and sequencing) for bacterial meningitis, early-onset neonatal sepsis, and spontaneous bacterial peritonitis. Diagn Microbiol Infect Dis. 2011:69:153-60.

50. Smith CJ, Osborn AM. Advantages and limitations of quantitative PCR (QPCR)-based approaches in microbial ecology. FEMS Microbiol Ecol. 2009;67: 6-20.

51. Abelian A, Pritchard I, Turner J, Dear PH. Paradigm shift in neonatal microbiology. Welsh Paed J. 2015;43:30-1.

52. Arnon S, Litmanovitz I. Diagnostic tests in neonatal sepsis. Curr Opin Infect Dis. 2008:3:223-7.

53. Davies EG, Elliman DAC, Hart CA, et al. Manual of childhood infections. London: Saunders Ltd; 2001.

54. Bacterial meningitis and meningococcal septicaemia in children. National Institute for Health and Care Excellence Clinical Guideline 102 (2010). Available at https://www.nice.org.uk/guidance/cg102/evidence/fullguideline-pdf-134564941, p. 122 (last accessed June 2020).

55. Bujang MA, Adnan TH. Requirements for minimum sample size for sensitivity and specificity analysis. J Clin Diagn Res. 2016;10:YE01-6.

\section{Publisher's Note}

Springer Nature remains neutral with regard to jurisdictional claims in published maps and institutional affiliations.

Ready to submit your research? Choose BMC and benefit from:

- fast, convenient online submission

- thorough peer review by experienced researchers in your field

- rapid publication on acceptance

- support for research data, including large and complex data types

- gold Open Access which fosters wider collaboration and increased citations

- maximum visibility for your research: over $100 \mathrm{M}$ website views per year

At BMC, research is always in progress.

Learn more biomedcentral.com/submissions 